\title{
Mueller matrix mapping of biological polycrystalline layers using reference wave
}

\author{
A.Dubolazov ${ }^{1}$, O.G. Ushenko ${ }^{1}$, Yu.O. Ushenko², L.Y. Pidkamin ${ }^{1}$, M.I. Sidor ${ }^{1}$, M. Grytsyuk ${ }^{2}$, P.V. \\ Prysyazhnyuk ${ }^{2}$ \\ ${ }^{1}$ Chernivtsi National University, 2 Kotsiubynskyi St., Chernivtsi, Ukraine, 58012 \\ 2 Bukovinian State Medical University, 3 Theatral Sq., Chernivtsi, Ukraine, 58000
}

\begin{abstract}
The paper consists of two parts. The first part is devoted to the short theoretical basics of the method of differential Mueller-matrix description of properties of partially depolarizing layers. It was provided the experimentally measured maps of differential matrix of the 1st order of polycrystalline structure of the histological section of brain tissue. It was defined the statistical moments of the1st-4th orders, which characterize the distribution of matrix elements. In the second part of the paper it was provided the data of statistic analysis of birefringence and dichroism of the histological sections of mice liver tissue (normal and with diabetes). It were defined the objective criteria of differential diagnostics of diabetes.
\end{abstract}

Keywords: Mueller matrix, biological layers, diagnostic, interference.

\section{INTRODUCTION}

\subsection{Brief theory of the method}

The theoretical basis of Mueller matrix approach to description of the interaction of optical radiation with multiple scattering layers is shown in a series of publications ${ }^{1-9}$. It was shown that polarization properties of partially depolarizing layer are described by means of differential matrix of the 1st order $\{m\}$

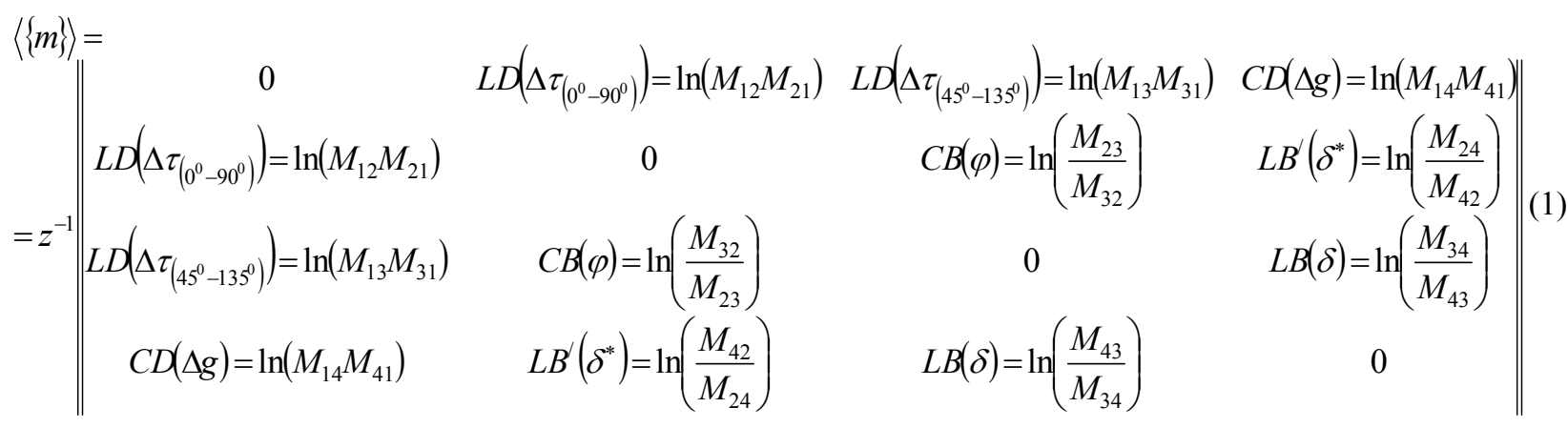

Here:

- $L D$ and $L B$ - linear dichroism and birefringence for the direction of the optical axis $\gamma=0^{0}$;

- $L D^{\prime}$ and $L B^{\prime}-$ linear dichroism and birefringence for the direction of the optical axis $\gamma=45^{0}$;

- $\quad C D$ and $C B$ - circular dichroism and birefringence;

- $\quad M_{i k}$ - Mueller-matrix elements ${ }^{10-19}$;

- $\delta$ and $\delta^{*}$ - phase shift between orthogonally-polarized $\left(0^{0}-90^{0}\right.$ and $\left.45^{\circ}-135^{\circ}\right)$ components of the laser light amplitude;

- $\Delta n_{L B}$ and $\Delta n_{L B}^{*}$ - linear birefringence values for $0^{0}-90^{\circ}$ and $45^{\circ}-135^{\circ}$; 
- $\varphi$ - phase shift between the right- $(\otimes)$ and left- $(\oplus)$ circularly polarized components of the laser light amplitude;

- $\Delta n_{C B}-$ circular birefringence value;

- $\Delta \tau_{\left(0^{0}-90^{0}\right)}$ and $\Delta \tau_{\left(45^{0}-135^{0}\right)}$ - ratio of absorption coefficients of the orthogonally-polarized $\left(0^{0}-90^{0}\right.$ and $45^{0}-135^{0}$ ) components of laser light amplitude;

- $\quad \chi_{\otimes}$ and $\chi_{\oplus}-$ absorption coefficients of right- $(\otimes)$ and left- $(\oplus)$ circularly polarized components of the laser light amplitude;

Such a parameters are in particular investigated for optically thin (non-depolarizing) layers of the histological sections of biological tissues and films of biological liquids ${ }^{20-36}$. For depolarizing layers such data is not obtained. Thus, the use of ideology differential analysis of Mueller matrix mapping data allowed us to obtain a set of algorithms of polarization reconstruction of average values of phase and amplitude anisotropy parameters of polycrystalline component of biological layer.

In the basis of the method of 3D Mueller-matrix mapping we put the results obtained in ${ }^{37,38}$. Here, the use of a reference wave of laser radiation, which in the scheme of optical interferometer is superimposed on a polarizationally inhomogeneous image of a biological layer is fundamental. The resulting interference pattern is recorded using a digital camera. With the use of diffraction integrals the operation of digital holographic reproduction of distributions of complex amplitudes $\left\{E_{x}(x, y) ; \quad E_{y}(x, y)\right\}$ of the objective field of a biological layer is performed ${ }^{39}$.

For each state of the irradiating beam, the reconstructed distributions of the Stokes vector parameters of the object field of a biological layer are calculated according to the reproduced distributions of complex amplitudes $\left\{E_{x}(x, y) ; \quad E_{y}(x, y)\right\}$

$$
\left(\begin{array}{l}
S_{1} \\
S_{2} \\
S_{3} \\
S_{4}
\end{array}\right)\left(0^{0}, 90^{0}, 45^{0}, \otimes\right)=\left(\begin{array}{c}
\left|E_{x}\right|^{2}+\left|E_{y}\right|^{2} \\
\left|E_{x}\right|^{2}-\left|E_{y}\right|^{2} \\
2 \operatorname{Re}\left|E_{x} E_{y}^{*}\right| \\
2 \operatorname{Im}\left|E_{x} E_{y}^{*}\right|
\end{array}\right) \Rightarrow\left\|M_{i k}(\delta)\right\| \Rightarrow\left\|\left\{m_{i k}\right\}\right\|
$$

Therefore, the direct Muller-matrix mapping results in two-dimensional distributions of the values of matrix elements $m_{i k}=q_{j}\left(S_{z=1 ; 2 ; 3 ; 4}(x, y, \delta)\right)$, averaging $(\delta(z=l))$ over the entire thickness $l$ of the biological layer.

\subsection{Experimental results of the method of Mueller-matrix mapping}

We obtain an expression for calculating elements of differential matrix of the 1st order:

$$
\begin{aligned}
& \langle\{m\}\rangle= \\
& =z^{-1} \| \begin{array}{cccc}
0 & \ln \left(0.25\left(V_{1}^{0}-V_{1}^{90}\right)\left(V_{2}^{0}+V_{2}^{90}\right)\right) & \left.0.5 \ln \left(V_{1}^{45}-M_{11}\right)\left(V_{3}^{0}+V_{3}^{90}\right)\right) & 0.5 \ln \left(\left(V_{1}^{\otimes}-M_{11}\right)\left(V_{4}^{0}+V_{4}^{90}\right)\right) \mid \\
\ln \left(0.5\left(V_{1}^{0}-V_{1}^{90}\right) 0.5\left(V_{2}^{0}+V_{2}^{90}\right)\right) & 0 & \ln \left(\frac{V_{2}^{45}-M_{21}}{0.5\left(V_{3}^{0}-V_{3}^{90}\right)}\right) & \ln \left(\frac{V_{2}^{45}-M_{21}}{0.5\left(V_{4}^{0}-V_{4}^{90}\right)}\right) \\
\left.0.5 \ln \left(V_{1}^{45}-M_{11}\right)\left(V_{3}^{0}+V_{3}^{90}\right)\right) & \ln \left(\frac{0.5\left(V_{3}^{0}-V_{3}^{90}\right)}{V_{2}^{45}-M_{21}}\right) & 0 & \ln \left(\frac{V_{3}^{\otimes}-M_{31}}{V_{4}^{45}-M_{41}}\right) \\
\ln \left(M_{14} M_{41}\right) & \ln \left(\frac{0.5\left(V_{4}^{0}-V_{4}^{90}\right)}{V_{2}^{45}-M_{21}}\right) & \ln \left(\frac{V_{4}^{45}-M_{41}}{V_{3}^{\otimes}-M_{31}}\right) & 0
\end{array} \mid(3)
\end{aligned}
$$

Here $V_{i=1 ; 2 ; 3 ; 4}^{0 ; 45 ; 0}$ - Stokes vectors of differently polarized beams ${ }^{10-13}$.

The results of studies of the two-dimensional structure of the elements $\left(\left(\left\langle m_{12}\right\rangle=\left\langle m_{21}\right\rangle\right) ;\left(\left\langle m_{13}\right\rangle=\left\langle m_{31}\right\rangle\right) ;\left(\left\langle m_{14}\right\rangle=\left\langle m_{41}\right\rangle\right) ;\left\langle\left(\left\langle m_{23}\right\rangle=-\left\langle m_{32}\right\rangle\right) ;\left\langle\left(m_{24}\right\rangle=-\left\langle m_{42}\right\rangle\right) ;\left(\left\langle m_{34}\right\rangle=-\left\langle m_{43}\right\rangle\right)\right)\right.$ of the differential matrix of the 
1st order (ratio (2)) of the histological section of brain tissue $(z=60 \mu \mathrm{m} ; \tau=0,21 ; \Lambda=43 \%, z$ - geometrical thickness; $\tau$ - extinction coefficient; $\Lambda$ - depolarization degree) are illustrated by a series of dependencies (maps and histograms of $m_{i k}$ distributions), which are shown in Fig. 1 and Fig. 2
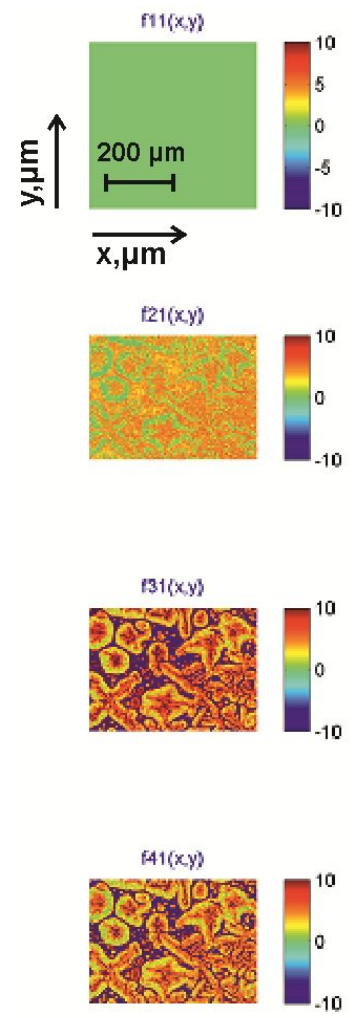
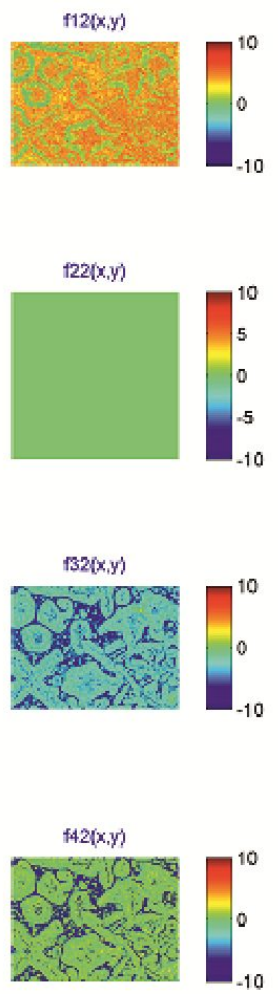
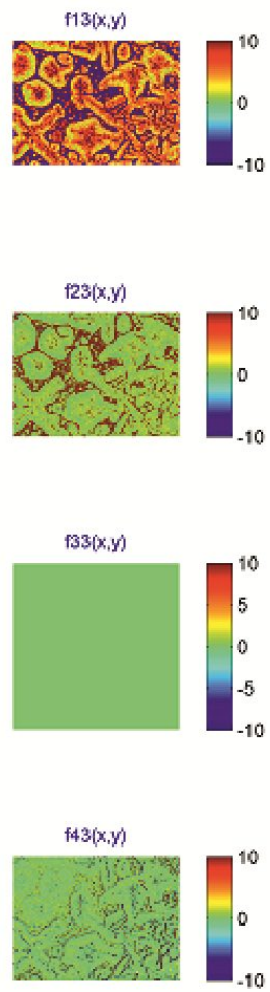
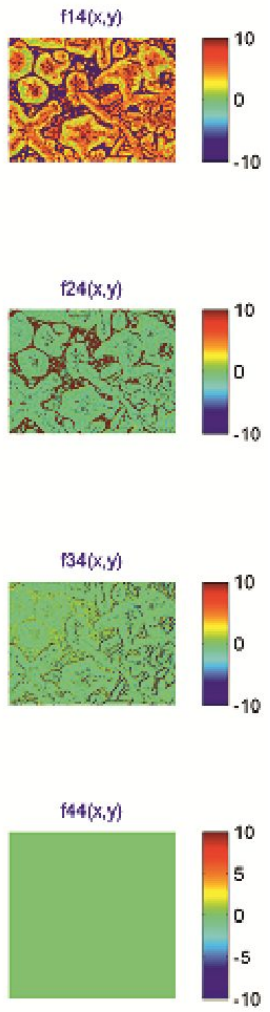

Fig. 1. Maps of elements of the 1st-order differential matrix of a histological section of brain $(z=60 \mu m ; \tau=0,21 ; \Lambda=43 \%)$.

It follows from the data obtained that non-zero values of all (except the diagonal $\left\langle m_{11 ; 22 ; 3 ; 44}\right\rangle$ ) elements of the differential matrix of the 1st order, which characterize the optical (phase and amplitude) anisotropy of the brain tissue layer. Good correlation was found between the theoretical $((1),(2))$ and experimental (Fig. 1) data on the symmetry of the $1^{\text {st }}$-order differential matrix of a partially depolarizing biological layer $\left(\left\langle m_{12}\right\rangle=\left\langle m_{21}\right\rangle\right) ;\left(\left\langle m_{13}\right\rangle=\left\langle m_{31}\right\rangle\right) ;\left(\left\langle m_{14}\right\rangle=\left\langle m_{41}\right\rangle\right) ;\left(\left\langle m_{23}\right\rangle=-\left\langle m_{32}\right\rangle\right) ;\left(\left\langle m_{24}\right\rangle=-\left\langle m_{42}\right\rangle\right) ;\left(\left\langle m_{34}\right\rangle=-\left\langle m_{43}\right\rangle\right)$.

In other words, the results of experimental measurements of the ensemble of six elements of this matrix operator enables to make a direct analysis of the average parameters of optical anisotropy $\left(L D=\left\langle m_{12 ; 21}\right\rangle ; C D=\left\langle m_{13 ; 31}\right\rangle ; L D^{\prime}=\left\langle m_{14 ; 41}\right\rangle ; L B=\left\langle m_{34 ; 43}\right\rangle ; C B=\left\langle m_{23 ; 32}\right\rangle ; L B^{\prime}=\left\langle m_{24 ; 42}\right\rangle\right)$ of the multiply scattering biological layer. 

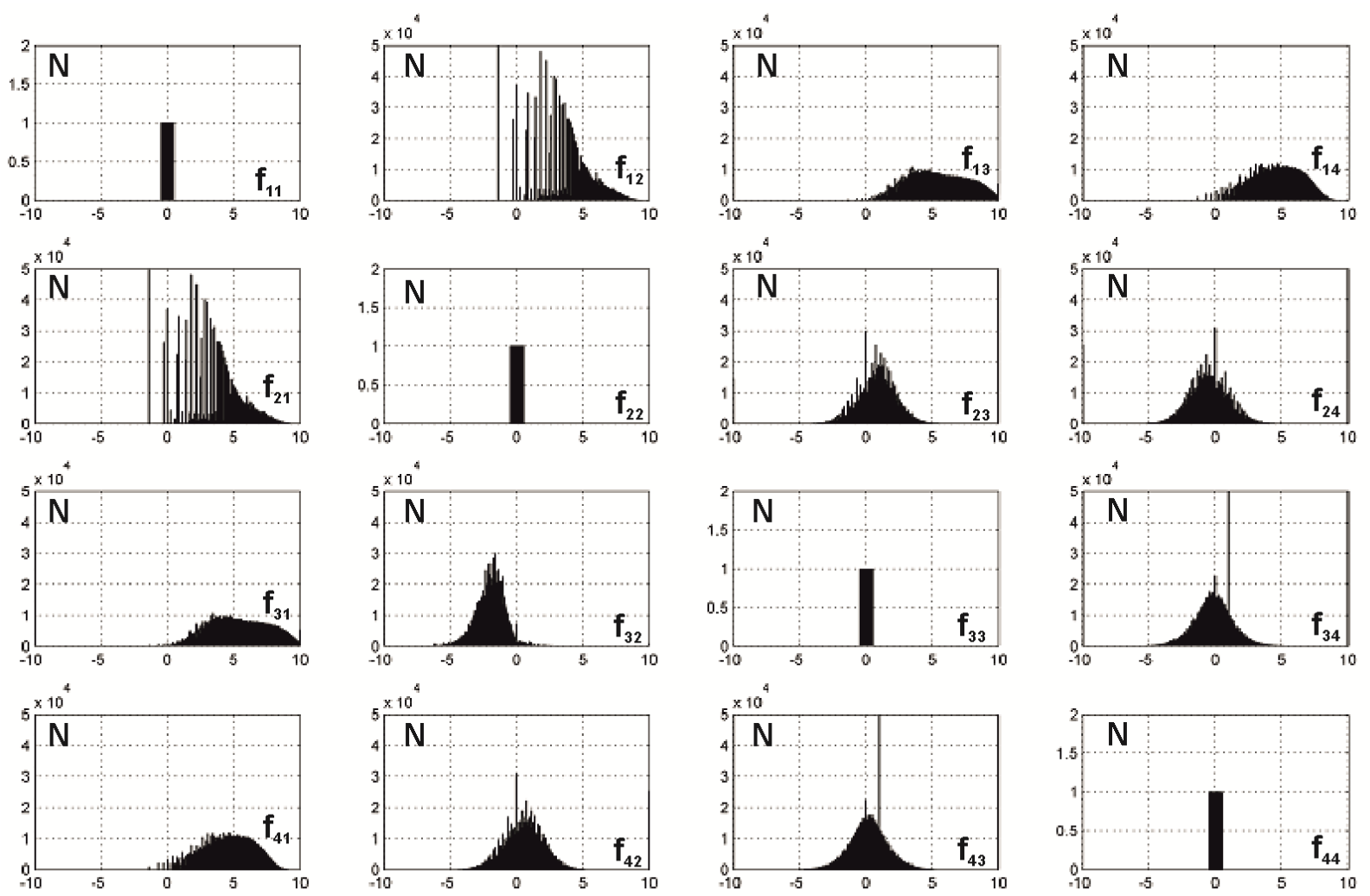

Fig. 2. Histograms of distribution of values of the 1st-order differential matrix elements of a histological section of brain $(z=60 \mu m ; \tau=0,21 ; \Lambda=43 \%)$.

Table 1 presents the results of statistic analysis (statistical moments of the 1 st- 4 th orders $Z_{i=1 ; 2 ; 3 ; 4}$ ) of coordinate distributions of the values of elements of differential Mueller matrix of the 1st order.

Table 1. Statistical moments $Z_{i=1 ; 2 ; 3 ; 4}$ of the distributions of anisotropy parameters of depolarizing layer of brain tissue

\begin{tabular}{|c|c|c|c|c|c|c|}
\hline$Z_{i=1 ; 2 ; 3 ; 4}$ & $m_{12}$ & $m_{13}$ & $m_{14}$ & $m_{23}$ & $m_{24}$ & $m_{34}$ \\
\hline$Z_{i=1}$ & 2,11 & 3,21 & 4,07 & 0,88 & 0,57 & 0,34 \\
\hline$Z_{i=2}$ & 2,71 & 1,98 & 2,28 & 0,56 & 0,39 & 0,22 \\
\hline$Z_{i=3}$ & 1,44 & 0,89 & 1,14 & 0,32 & 0,17 & 0,49 \\
\hline$Z_{i=4}$ & 1,81 & 0,56 & 0,41 & 0,21 & 0,44 & 0,35 \\
\hline
\end{tabular}

It was defined the individual sensitivity of the value of $Z_{i=1 ; 2 ; 3 ; 4}$ to the peculiarities of coordinate distributions of optical anisotropy parameters of partially depolarizing layer of brain tissue. Such a fact was chosen as the basic for applied biomedical usage of statistic analysis of coordinate distributions of both birefringence and dichroism. 


\section{CLINICAL APPLICATION OF MUELLER-MATRIX MAPPING OF BIOLOGICAL LAYERS IN DIFFERENTIAL DIAGNOSTICS OF DIABETES}

\subsection{Objects of investigation}

It was investigated two groups of samples of the histological sections of mice liver tissue:

- $\quad$ healthy animals - control group 1 (36 samples);

- $\quad$ affected by diabetes - investigated group 2 (36 samples).

Histological sections were produced due to the standard technique on the freezing microtome.

\subsection{Experimental results}

The set of Figs. 3, 4 presents the results of differential Mueller-matrix mapping of the distributions of linear birefringence (Fig.3) and dichroism (Fig.4) of the histological sections of mice liver tissue from group 1 (fragments 1,3) and group $2(2,4)$.

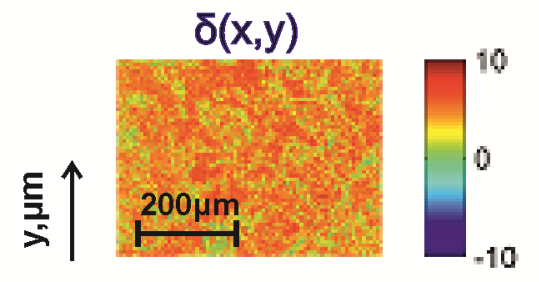

$\overrightarrow{x, \mu m}$

(1)

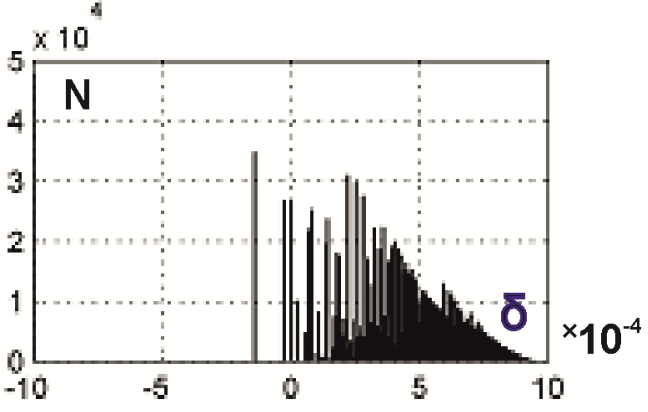

(3)

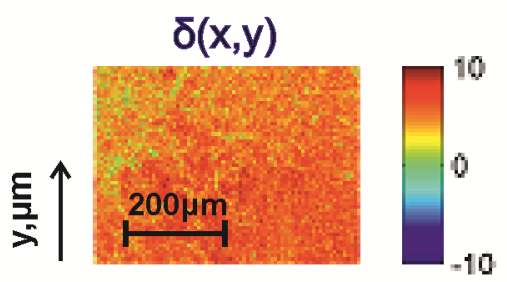

$\overrightarrow{x, \mu m}$

(2)

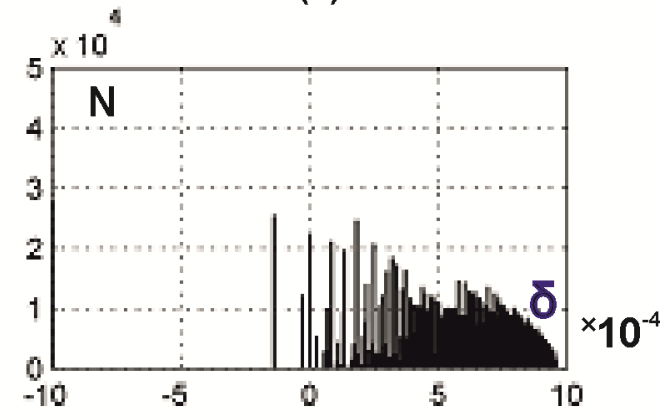

(4)

Fig. 3. Maps ((1),(2)) and histograms ((3),(4)) of the distribution of the values of linear birefringence of the histological sections of mice liver tissue of healthy $(1,3)$ and affected by diabetes $(2,4)$ animals. 


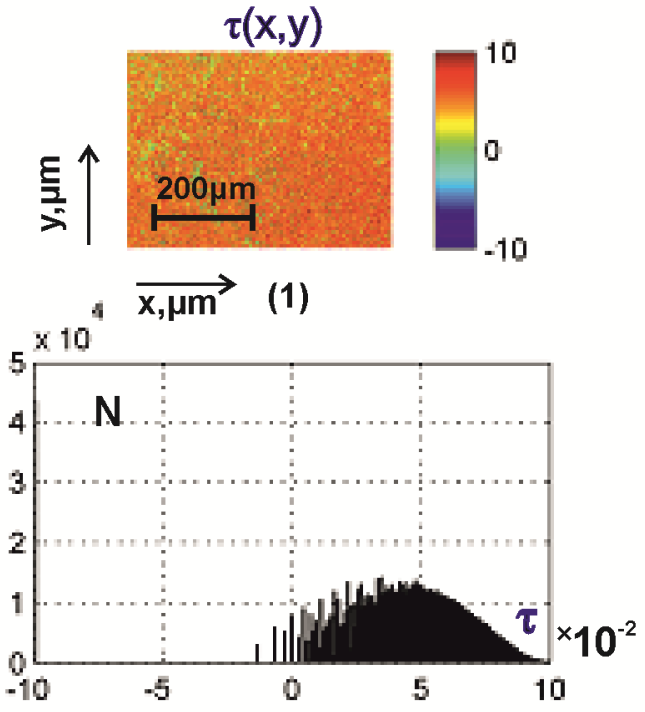

(3)
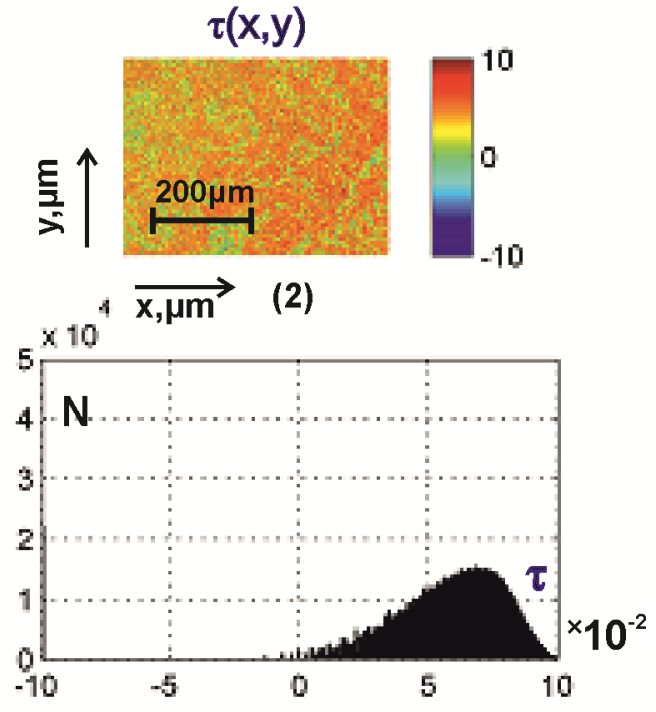

(4)

Fig. 4. Maps ((1),(2)) and histograms ((3),(4)) of the distribution of the values of linear dichroism of the histological sections of mice liver tissue of healthy $(1,3)$ and affected by diabetes $(2,4)$ animals.

For the possible clinical application of the Mueller matrix mapping method for each group of samples the operating characteristics, typical for evidence-based medicine ${ }^{40-42}$ that determine the diagnostic power of the method are determined, namely - sensitivity $\left(S e=\frac{a}{a+b} 100 \%\right)$, specificity $\left(S p=\frac{c}{c+d} 100 \%\right)$ and balanced accuracy ( $A c=\frac{S e+S p}{2}$ ), where $a$ and $b$ - the number of correct and incorrect diagnoses within group 2;c and $d$ - the same within group 1 - Table 2.

Table 2. Balanced accuracy of the method of differential Mueller-matrix mapping

\begin{tabular}{|c|c|c|}
\hline$A c, \%$ & $\delta$ & $\tau$ \\
\hline$Z_{i=1}$ & $71 \%$ & $84 \%$ \\
\hline$Z_{i=2}$ & $84 \%$ & $81 \%$ \\
\hline$Z_{i=3}$ & $90 \%$ & $86 \%$ \\
\hline$Z_{i=4}$ & $95 \%$ & $91 \%$ \\
\hline
\end{tabular}

It was reached good $(A c(\tau)=86 \%-91 \%)$ and excellent $(A c(\delta)=95 \%)$ level of balanced accuracy of differential diagnostics of the samples of mice liver tissue of healthy and affected by diabetes animals.

\section{CONCLUSIONS}

Short theoretical basics of the method of differential Mueller-matrix mapping of polycrystalline structure of depolarizing biological layers were provided. It was demonstrated the results of experimental approbation of such method and defined the parameters of differential Mueller matrix of the 1st order of brain tissue histological section. The differential diagnostics was realized by means of statistic analysis of coordinate distribution of the parameters of linear birefringence and dichroism of the samples of mice liver tissue - healthy and with diabetes. It was reached a good and excellent levels of balanced accuracy of differential diagnostics of the samples of mice liver tissue for healthy and affected by diabetes animals. 


\section{REFERENCES}

[1] R. M. A. Azzam, Propagation of partially polarized light through anisotropic media with or without depolarization J. Opt. Soc. Am. 68 (1978) 1756-1767.

[2] R.C. Jones, A new calculus for the treatment of optical systems. VII properties of the N-matrices, J. Opt. Soc. Am. 38 (1948) 671-685.

[3] N. Ortega-Quijano, J.L. Arce-Diego, Mueller matrix differential decomposition, Opt. Letters 36 (2011) 19421944.

[4] N. Ortega-Quijano, J.L. Arce-Diego, Depolarizing differential Mueller matrices, Opt. Letters 36 (2011) 24292431.

[5] V. Devlaminck, Physical model of differential Mueller matrix for depolarizing uniform media, J. Opt. Soc. Am. 30 (2013) 2196-2204.

[6] R. Ossikovski, V. Devlaminck, General criterion for the physical reliability of the differential Mueller matrix, Opt. Lett. 39 (2014) 1216-1219.

[7] V. Devlaminck, R. Ossikovski, Uniqueness of the differential Mueller matrix of uniform homogeneous media, Opt. Lett. 39 (2014) 3149-3152.

[8] R. Ossikovski, O. Arteaga, Statistical meaning of the differential Mueller matrix of depolarizing homogeneous media, Opt. Lett. 39 (2014) 4470-4473.

[9] R. Ossikovski, Differential matrix formalism for depolarizing anisotropic media, Opt. Letters. 36 (2011) 23302332.

[10] Angel'skiǐ, O.V., Ushenko, A.G., Ermolenko, S.B.,Ushenko, Yu.A., Pishak, O.V., "Polarization Based Visualization of Multifractal Structures for the Diagnostics of Pathological Changes in Biological Tissues," Optics and Spectroscopy (English translation of Optika i Spektroskopiya) 89 (5), 799-804 (2000).

[11] Ushenko, A.G., "Polarization Correlometry of Angular Structure in the Microrelief Pattern of Rough Surfaces," Optics and Spectroscopy (English translation of Optika i Spektroskopiya) 92, 227-229 (2002).

[12] Ushenko, A.G., Burkovets, D.N., Ushenko, Yu.A., "Polarization Phase Mapping and Reconstruction of Biological Tissue Architectonics during Diagnosis of Pathological Lesions," Optics and Spectroscopy (English translation of Optika i Spektroskopiya) 93 (3), 449-456 (2002).

[13] Angelsky, O.V., Ushenko, A.G., Ushenko, Y.G., "Complex degree of mutual polarization of biological tissue coherent images for the diagnostics of their physiological state," Journal of Biomedical Optics 10 (6), 060502060502-3 (2005).

[14] Angelsky, O. V., Bekshaev, A. Ya., Maksimyak, P. P., Maksimyak, A. P., Hanson, S. G., Zenkova, C. Yu., "Selfdiffraction of continuous laser radiation in a disperse medium with absorbing particles," Optics Express 21(7), 8922-8938 (2013).

[15] Angelsky, O.V., Bekshaev, A. Ya., Maksimyak, P. P., Maksimyak, A. P., Hanson, S.G. ,Zenkova, C. Yu., "Selfaction of continuous laser radiation and Pearcey diffraction in a water suspension with light-absorbing particles," Optics Express 22(3), 2267-2277 (2014).

[16] Angelsky, O. V., Bekshaev, A. Ya., Maksimyak, P. P., Maksimyak, A. P., Hanson, S. G., "Measurement of small light absorption in microparticles by means of optically induced rotation," Optics Express 23(6), 7152-7163 (2015).

[17] Polyanskii, V.K., Angelsky, O.V., Polyanskii, P.V., "Scattering-induced spectral changes as a singular optical effect," Optica Applicata 32 (4), 843-848 (2002).

[18] V. V. Tuchin, L. Wang, and D. À. Zimnyakov, Optical Polarization in Biomedical Applications, New York, USA, 2006.

[19] R. A. Chipman, Polarimetry in Handbook of Optics: Vol. I- Geometrical and Physical Optics, Polarized Light, Components and Instruments, M. Bass, Ed., McGraw-Hill Professional, New York, 2010, pp. 22.1-22.37.

[20] Angelsky, O.V., Besaha, R.N., Mokhun, A.I., Mokhun, I.I., Sopin, M.O., Soskin, M.S., "Singularities in vectoral fields," Proc. SPIE 3904, 40-54 (1999).

[21] Angelsky, O.V., Tomka, Y.Y., Ushenko, A.G., Ushenko, Y.G., Yermolenko, S.B., "2-D tomography of biotissue images in pre-clinic diagnostics of their pre-cancer states," Proc. SPIE 5972, 158-162 (2005).

[22] Yu.A. Ushenko, V.A. Ushenko, A.V. Dubolazov, V.O. Balanetskaya, N.I. Zabolotna, "Mueller-matrix diagnostics of optical properties of polycrystalline networks of human blood plasma," Optics and Spectroscopy 112, 884-892 (2012). 
[23] V.A. Ushenko, O.V. Dubolazov, A.O. Karachevtsev, "Two wavelength Mueller matrix reconstruction of blood plasma films polycrystalline structure in diagnostics of breast cancer," Appl. Opt. 53, B128-B139 (2014).

[24] Y.A. Ushenko, G.D. Koval, A.G. Ushenko, O.V. Dubolazov, V.A. Ushenko, O.Yu. Novakovskaia, "Muellermatrix of laser-induced autofluorescence of polycrystalline films of dried peritoneal fluid in diagnostics of endometriosis," J. Biomed. Opt. 21(7), 071116 (2016).

[25] A.G. Ushenko, A.V. Dubolazov, V.A. Ushenko, O.Y. Novakovskaya, "Statistical analysis of polarizationinhomogeneous fourier spectra of laser radiation scattered by human skin in the tasks of differentiation of benign and malignant formations," J. Biomed. Opt. 21(7), 071110 (2016).

[26] V.P. Prysyazhnyuk, Yu.A. Ushenko, A.V. Dubolazov, A.G. Ushenko, V.A. Ushenko, "Polarization-dependent laser autofluorescence of the polycrystalline networks of blood plasma films in the task of liver pathology differentiation," Appl. Opt. 55, B126-B132 (2016).

[27] Angelsky, O.V., Yermolenko, S.B., Prydij, O.G., Ushenko, A.G., Ushenko, Ye.G. "Polarization-interference structure of speckle fields of the rough skin surface," J. Holography Speckle, 3, 27-34 (2006).

[28] Angelsky, P. O., Ushenko, A. G., Dubolazov, A. V., Sidor, M. I., Bodnar, G. B., Koval, G., Trifonyuk, L., "The singular approach for processing polarization-inhomogeneous laser images of blood plasma layers," Journal of Optics 15(4), 044030 (2013).

[29] V. A. Ushenko, N. I. Zabolotna, S. V. Pavlov, D. M. Burcovets, O. Yu. Novakovska, "Mueller-matrices polarization selection of two-dimensional linear and circular birefringence images," Proc.SPIE 9066, (2013).

[30] V. A. Ushenko, A. V. Dubolazov, "Correlation and self similarity structure of polycrystalline network biological layers Mueller matrices images,” Proc. SPIE 8856, (2013).

[31] Yu. A. Ushenko, V. A. Ushenko, A. V. Dubolazov, V. O. Balanetskaya, N. I. Zabolotna, "Mueller-matrix diagnostics of optical properties of polycrystalline networks of human blood plasma," Optics and Spectroscopy 112(6), 884-892 (2012).

[32] Yu. A. Ushenko, A. V. Dubolazov, V. O. Balanetskaya, A. O. Karachevtsev, V. A. Ushenko, "Wavelet-analysis of polarization maps of human blood plasma," Optics and Spectroscopy, 113(3), 332-343. (2012).

[33] V. O. Ushenko "Spatial-frequency polarization phasometry of biological polycrystalline networks" Optical Memory and Neural Networks, 22(1), 56-64 (2013).

[34] Gruia, I., Yermolenko, S.B., Gruia, M., Ivashko, P.V., Stefanescu, T., "Spectral and biochemical methods for identification of cellular and tissues malignant changes," Optoelectronics and Advanced Materials - Rapid Communication, 4(4), 523-526 (2010).

[35] Yermolenko, S.B., Ivashko, P.V., Prydij,A.G., Gruia, I. "Statistical analysis of polarized images of biotissues for diagnose of their pathological changes," Optoelectronics and advanced materials - rapid comunications, 4 (4), 527-530 (2010).

[36] V. A. Ushenko, O. V. Dubolazov, A. O. Karachevtsev, "Two wavelength Mueller matrix reconstruction of blood plasma films polycrystalline structure in diagnostics of breast cancer," Applied Optics. 53(10), B128-B139 (2014).

[37] D. K. Kasaragod et al., "Experimental validation of an extended Jones matrix calculus model to study the 3D structural orientation of the collagen fibers in articular cartilage using polarization-sensitive optical coherence tomography," Biomed. Opt. Express 3(3), 378-387 (2012).

[38] Y. Yasuno et al., "Jones Matrix based polarization sensitive optical coherence tomography," in Optical Coherence Tomography: Technology and Applications, 2nd ed., W. Drexler and J. G. Fujimoto, Eds., pp. 1137-1162, Springer Reference, Science + Business Media, New York (2015)

[39] J. Tervo, T. Setala, A. Friberg, "Degree of coherence for electromagnetic fields," Opt. Express 11, 1137-1143 (2003).

[40] L. Cassidy, "Basic concepts of statistical analysis for surgical research," Journal of Surgical Research 128, 199206 (2005).

[41] C. S. Davis, "Statistical methods of the analysis of repeated measurements," New York: Springer-Verlag, 744, (2002).

[42] A. Petrie, B. Sabin, “Medical Statistics at a Glance,” Blackwell Publishing, 157, (2005). 